\title{
FARMERS CHOICE OF PESTICIDES FOR THE MANAGEMENT OF WHITEFLY OF COTTON IN PUNJAB, PAKISTAN
}

Zulfiqar Ali Ghori ${ }^{1}$, Habib Anwar ${ }^{2}$, Areeba Ghori ${ }^{2}$

${ }^{1}$ Pest warning \& Quality Control of pesticides, Punjab, Pakistan.

${ }^{2}$ Department of Soil Science, University of Agriculture, Faisalabad, Pakistan.

\section{A R T I C L E I N F O}

\section{Article history}

Received: $13^{\text {th }}$ May, 2019

Revised: 29th July, 2019

Accepted: $28^{\text {th }}$ August, 2019

Keywords

Whitefly

Insecticide

Preference

Management

\section{A B S T R A C T}

Cotton, popularly known as white gold, is the king of natural fiber and an important cash crop of Pakistan which earns foreign exchange up to 11.7\% and 2.9\% of GDP. The present study was carried out in cotton growing areas of four divisions of Punjab to determine the choice of cotton growers for the selection of pesticides for the management of whitefly. The data of hot spots of whitefly were recorded twice a week from April to October during 2015, 2016 and 2017 by using the standard pest scouting method. The study revealed that an increase of $16.09 \%$ hot spots of whitefly was detected in 2017 as compared to previous two consecutive years (2015 and 2016). Regarding farmers' choice for selection of pesticides used to control whitefly, the farmers used Imidacloprid, Acetamiprid, Buprofezin, Clothinadin, Diafenthiuron, Flonicamid, Matrine, Pyriproxifen, Pymetrozine, Spirotetramat. The comparison of three years indicated that maximum farmers preferred to spray Pyriproxifen on the hot spots of cotton whitefly followed by Buprofezin, Acetamiprid and Diafenthiuronwhile Clothinadin and Matrine were used by the minimum numbers of farmers. The use of these insecticides by the farmers during the three years was nonsignificant. The farmers preferred these pesticides being of third generation, IGRs, Neonicotinoids, environment friendly to human health and safer to natural enemies of whitefly.

Corresponding Author: Zulfiqar Ali Ghori

Email: zaghoriada@gmail.com

(C) 2018 EScience Press. All rights reserved.

\section{INTRODUCTION}

Cotton (Gossypium sp.) is the king of natural fiber which is grown in 111 countries of the world. It is cultivated on an area of about 3.12 hectares in Pakistan which produce foreign exchange to the tune of $11.7 \%$ and contributes a share of $2.9 \%$ in GDP. It is a perennial semi-shrub grown as an annual crop in both tropical and warm temperate regions. Each and every part of cotton plants is useful for the farmers in one way or the other (Anonymous, 2003,
2005). It is also a source of oil and animal feed. Cotton plays a pivotal role in Pakistan's economy being a dominant factor in industrial and agricultural sectors. It has attained a unique value in social affairs. Many allied activities like ginning, animal feed, fabric production, textile processing, garments manufacturing, and their marketing have renowned its status to a maximum level in international market.

Cotton is very sensitive to many factors such as water, 
temperature, humidity, rainfall etc. but the insect pests have been observed the most important which have threatened the cotton crop with a damage of $5-10 \%$ while the crop has been severely attacked by insect pests causing losses in yield up to $40-50 \%$ (Naqvi, 1976). About 20-40\% yield losses have been estimated in Pakistan (Ahmad, 1999) despite of its cultivation on large acreage. The farmers have been facing many problems of sucking pests' complex and they have to adopt different control methods depending predominantly on chemical control. Among sucking insect pests, Bemisia tabaci (Genn.), Aphis gossypi (Glover), Thrips tabaci (Lind.) and Amrasca bigutella bigutella (Dist.) cause significant losses in yield and cause 40-50\% damage to the crop (Amjad and Aheer, 2007; Aslam et al., 2004; Nizamani et al., 2002). Cotton whitefly causes $50 \%$ cut back in boll production by sucking cell sap and secreting honey dews which is a source of sooty mold development (Ahmad et al., 2002). It also transmits cotton leaf curl virus disease (CLCuV) (Nelson et al., 1998). The average yield loss in Pakistan caused by CLCuV was reported to be 38.7 \% during 1993 which is threatening our cotton-based economy.

In the recent past, B. tabaci, being polyphagous has become a destructive, injurious and major pest of cotton, vegetables and ornamentals (Byrne and Bellows, 1991; Deholm and Birnie, 1990; Henneberry and Bulter Jr, 1992). For the control of cotton whitefly, chemical control has become an important component of crop protection but its overdependence should be avoided under all circumstances. However, the management of B. tabaci with insecticides has been extensively depending upon organophosphates, pyrethroids, organochlorines and carbamates (Sharaf, 1986).

Insecticides with particular mode of action and selective specifications such as Imidacloprid, Pyriproxfen, Buprofezinand Diafenthiuronwere used for the management of all the developmental stages of cotton whitefly effectively (Horowitz et al., 1994). Insect growth regulators and new neonicotinoids have been found to be the most efficacious as compared to conventional insecticides on cotton against B. tabaci as these are less noxious for the predators of sucking insect pests (Aheer et al., 2002; Asi et al., 2008; Aslam et al., 2004; Frank, 2012; Solangi and Lohar, 2007).

The neonicotinoids are important due to their novel action against sucking insects (Anikwe et al., 2009; Carvalho et al., 2010; Iwasa et al., 2004; Zhang et al., 2011). The management of $B$. tabaci with insecticides is prudent and inevitable part of integrated pest management (Mohyuddin et al., 1997). In advanced countries of the world, $3 \%$ value of agriculture crops is meant for toxic chemicals and their application. An expenditure of more than 10 billion rupees is spent in Pakistan for the import of pesticides and $70-80 \%$ is used only against cotton pests (Aslam et al., 2004).

The present study was therefore, focused on the potential of farmers' choice for pesticides used in the management of cotton whitefly in the major cotton growing areas of Punjab, Pakistan.

\section{MATERIALS AND METHODS}

The studies regarding the choice of farmers for selection of pesticides to be used against cotton whitefly were conducted in major cotton growing areas of four divisions (Multan, Bahawalpur, Dera Ghazi Khan and Sahiwal) of Punjab, Pakistan. Pest scouting of cotton crop was conducted as per prescribed pest scouting method (Hussain, 2017) by examining upper, middle and lower leaves of twenty randomly selected plants from the fields under scouting in the cotton growing areas of Punjab, Pakistan to observe the attack of $B$. tabaci. Cotton fields were kept under keen observation from $1^{\text {st }}$ week of April to $4^{\text {th }}$ week of October. A total of 46823,54777 and 55429 spots were visited during 2015, 2016 and 2017 respectively in the study areas. Infestation of whitefly was recorded in each cotton field.

The farmers were advised by the officers of Pest Warning Wing of Agriculture Department to use recommended insecticides (branded or generic group) with recommended doses on hot spots (above ETL) for the control of cotton whitefly. The spots were also revisited, got verified for observing the treatment of a particular insecticide applied by the farmers on the fields and the data of such treated fields were recorded, collected from all the four divisions of cotton zone and tabulated for statistical analysis to record farmers choices towards pesticide use for the better management of B. tabaci in the cotton growing areas of Punjab, Pakistan.

Statistical analysis: Data were analyzed statistically by using R version 3.4.3 (Kite-Eating Tree). ANOVA was used for comparison between pesticides and years by using two factorial Completely Randomized Design.

\section{RESULTS}

The data of consecutive three years was recorded and analyzed statistically by applying ANOVA. The detail of spots is given in Table 1. A total of 46823,54777 and 55429 spots were visited during 2015, 2016 and 2017 respectively in the 
four cotton growing divisions. Out of total cotton spots, 11085 spots (23.67\%), 13565 spots $(24.76 \%)$ and 16168 spots (29.17\%) were found above ETL while the rest of the spots were below ETL. The spots of whitefly above ETL observed in 2017 were more than those of observed in the previous two years as shown in Table 1. This showed that this injurious sucking pest of cotton remained dominant during 2017 as compared to previous two years.

Table 1. Detail of cotton spots and infestation of white fly.

\begin{tabular}{llll}
\hline Spots & 2015 & 2016 & 2017 \\
\hline Spots above ETL & 11085 & 13565 & 16168 \\
percentage & 23.67 & 24.76 & 29.17 \\
Spots below ETL & 35738 & 41212 & 39261 \\
percentage & 76.33 & 75.24 & 70.83 \\
Total spots & 46823 & 54777 & 55429 \\
\hline
\end{tabular}

Regarding farmers' choice for selection of pesticides used to control whitefly, the farmers used Imidacloprid, Acetamiprid, Buprofezin, Clothinadin, Diafenthiuron, Flonicamid,Matrine, Pyriproxifen, Pymetrozine, Spirotetramat. The statistical analysis (Table 2) reflected that pesticides were highly significant at a probability level of $<0.001 \%$. The comparison of three years indicated that maximum farmers preferred to spray Pyriproxifenon the Table 2. ANOVA regarding spray preference.

\begin{tabular}{lllllll}
\hline Factor & Df & Sum Sq & Mean Sq & F-value & $\operatorname{Pr}(>\mathrm{F})$ \\
\hline Year & 2 & 0 & 0 & 0 & 2 & \\
Pesticides & 9 & 2179.6 & 242.18 & 82.93 & $2.46 \mathrm{E}-13$ & $* * *$ \\
\hline
\end{tabular}

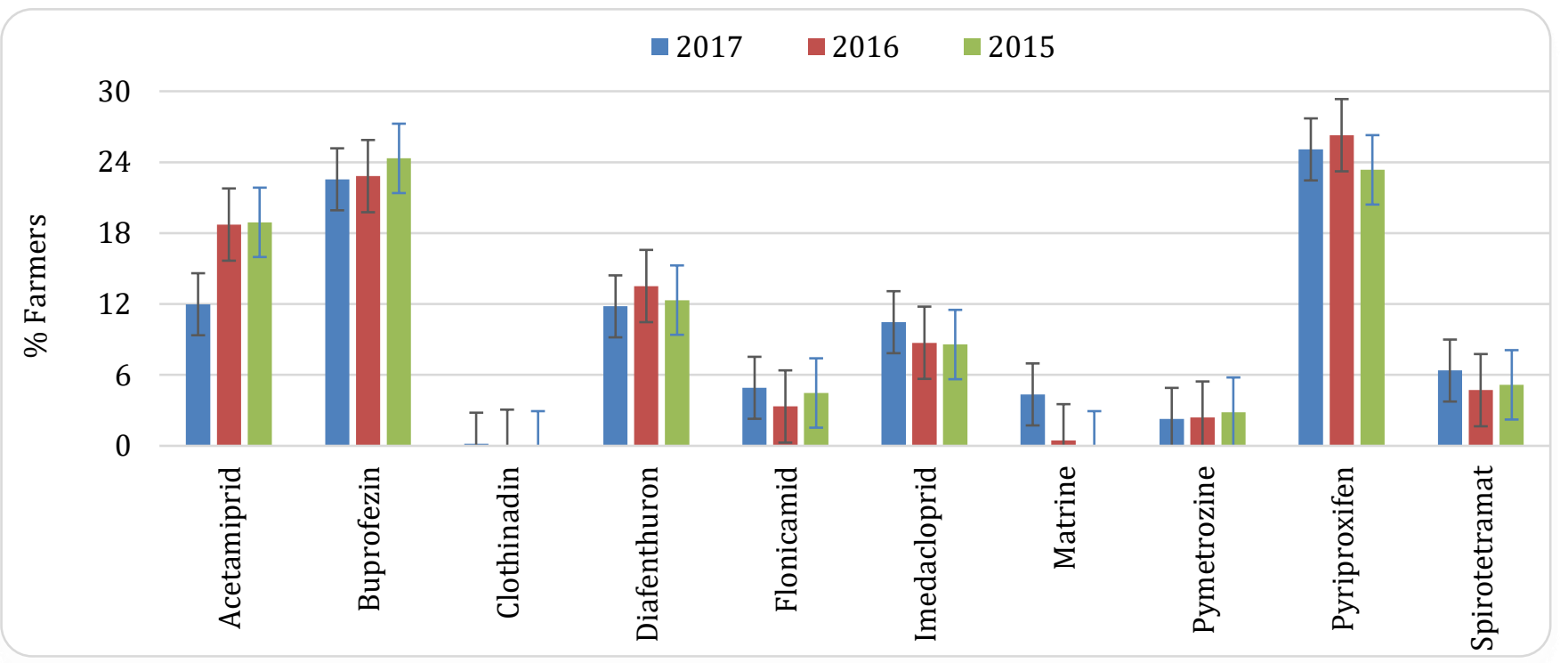

Figure 1. Year wise usage of insecticides for the control of whitefly of cotton.

\section{DISCUSSION}

Farmers' community mostly depends upon chemical control for the management of sucking insects due to hot spots of cotton whitefly followed by Buprofezin, Acetamiprid and Diafenthiuronwhile Clothinadin and Matrine were used by the minimum numbers of farmers as shown in figure 1 . The use of these insecticides by the farmers during the three years was non-significant. This showed that IGRs and Neonicotinoids being environment friendly occupied the maximum space of use by the farmers against cotton whitefly. 
secondary pests, environmental pollution and interruption of natural balance (Costa et al., 2003). The selective and effective use of chemicals at proper time is the most important tool to control the pests, safer for the beneficial fauna, reduction in resistance against certain chemicals in insect pests as well as minimum exposure to the human health.

The study revealed that the farmers preferred the pesticides against cotton whitefly which were IGRs, environment friendly, Neonicotinoids and less toxic to natural enemies. Our findings are compromising to the study of Costa et al. (2003). The use of Pyriproxifenduring the consecutive three years $(2015,2016$ and 2017) remained dominant, in lieu of farmers' choice, due to its prompt and novel action against whitefly. The present study is also similar and parallel to the findings of Iwasa et al. (2004); Zhang et al. (2011) and Carvalho et al. (2010) who determined that the neonicotinoids were important due to their novel action against sucking insects.

Most of the farmers opted for application of Pyriproxifen, Buprofezin, Imidacloprid, and Diafenthiurondue to their particular mode of action and specifications for all developmental stages of whitefly. Our study also coincides with the findings of Horowitz et al. (1994) who reported that the insecticides such as Pyriproxfen, Buprofezin, Diafenthiuronand Imidacloprid were used for the management of all developmental stages of cotton whitefly effectively.

Conclusion: It is concluded that the preferred pesticides used by the majority of the farmers against whitefly proved to be useful having significant importance than others for the best management of developmental stages of whitefly. It is recommended that the farmers should not espouse fully on chemicals rather it should be used as a part of integrated pest management so as to save environment, beneficial fauna and human health.

Author Contributions: ZAG planned and designed the studies, ZAG, HA and AG collected, analyzed data and wrote the manuscript.

Conflict of interest: The author declares no conflict of interest.

\section{REFERENCES}

Aheer, G.M., Ahmad, N., Karar, H., 2002. Chemical control of cotton whitefly adults, Bemisia tabaci (Genn.). Journal of Agriculture Research 38, 353-357.

Ahmad, M., Arif, M.I., Ahmad, Z., Denholm, I., 2002. Cotton whitefly (Bemisia tabaci) resistance to organophosphate and pyrethroid insecticides in Pakistan. Pest Management Science: formerly Pesticide Science 58, 203-208.

Ahmad, Z., 1999. Pest problems of cotton A Regional Perspective. Regional Consultation on Insecticide Resistance Management in Cotton June 28-July 01, 1999 1, 5-21.

Amjad, A., Aheer, G.M., 2007. Varietal resistance against sucking insect pests of cotton under Bahawalpur ecological conditions [Pakistan]. Journal of Agricultural Research 45, 205-208.

Anikwe, J.C., Asogwa, E.U., Ndubuaku, T.C.N., Okelana, F.A., 2009. Evaluation of the toxicity of Actara 25 WG for the control of the cocoa mirid Sahlbergella singularis Hagl.(Hemiptera: Miridae) in Nigeria. African Journal of Agriculture Research 8, 15281535.

Anonymous, 2003. Economic survey of Pakistan, Ministry of Food and Agriculture, Islamabad.

Anonymous, 2005. Training manual on DVS test in cotton with resistance to PPV and FR legislation. all India Coordinated Cotton Improvement Project CICR combatore Tamil Nadu, 134-135.

Asi, M.R., Afzal, M., Anwar, S.A., Bashir, M.H., 2008. Comparative efficacy of insecticides against sucking insect pests of cotton. Pakistan Journal of Life and Social Sciences 6, 140-142.

Aslam, M., Razaq, M., Shah, S.A., Ahmad, F., 2004. Comparative efficacy of different insecticides against sucking pests of cotton. Journal of Research Sciences 15, 53-58.

Aslam, M., Razzaq, M., Rana, S., Faheem, M., 2003. Efficacy of different insecticides against sucking insectpests on cotton. Pakistan Entomological Society 25, 155-159.

Byrne, D.N., Bellows, T.S.J., 1991. Whitefly biology. Annual review of entomology 36, 431-457.

Carvalho, G.A., Godoy, M.S., Parreira, D.S., Lasmar, O., Souza, J.R., Moscardini, V.F., 2010. Selectivity of growth regulators and neonicotinoids for adults of Trichogramma pretiosum (Hymenoptera: Trichogrammatidae). Revista Colombiana de Entomologia 36, 195-201.

Costa, D.B., Souza, B., Carvalho, G.A., Carvalho, C.F., 2003. Residual action of insecticides to larvae of Chrysoperla externa (Hagen, 1861)(Neuroptera: Chrysopidae) under greenhouse conditions. Ciência e Agrotecnologia 27, 835-839.

Deholm, I., Birnie, L.C., 1990. Prospects for managing resistance to insecticides in the whitefly, Cotton production research from a farming systems perspective, with special emphasis on stickiness: papers presented at a technical seminar at the 49th plenary meeting of the International Cotton 
Advisory Committee. International Cotton Advisory Committee, pp. 37-41.

Frank, S.D., 2012. Reduced risk insecticides to control scale insects and protect natural enemies in the production and maintenance of urban landscape plants. Environmental Entomology 41, 377-386.

Henneberry, T.J., Bulter Jr, G.D., 1992. Whiteflies as a factor in cotton production with specific reference to Bemisia tabaci (Gennadius), ProceedingsBeltwide Cotton Production Research Conferences (USA), pp. 674-683.

Horowitz, A.R., Forer, G., Ishaaya, I., 1994. Managing resistance in Bemisia tabaci in Israel with emphasis on cotton. Pesticide Science 42, 113-122.

Hussain, R., 2017. Pest Scouting Methods In Cotton Is Crucial To Your Higher Yield, Available at: http://www.agriculture.pk/pest-scoutingmethods-cotton/.

Iwasa, T., Motoyama, N., Ambrose, J.T., Roe, R.M., 2004. Mechanism for the differential toxicity of neonicotinoid insecticides in the honey bee, Apis mellifera. Crop Protection 23, 371-378.

Mohyuddin, A.I., Jilani, G., Khan, A.G., Hamza, A., Ahmed, I., Mahmood, Z., 1997. Integrated pest management of major cotton pests by conservation, redistribution and augmentation of natural enemies. Pakistan Journal of Zoology 29, 293-298.

Naqvi, K., 1976. Crop protection to boost up cotton production, Proceedings of Cotton Production Seminar, Organized by ESSO Fertilizer Company Limited Pakistan, pp. 119-125.

Nelson, M.R., Nadeem, A., Ahmed, W., Orum, T.V., 1998. Global assessment of cotton virus disease, Beltwide Cotton Conferences (USA), pp. 161-162.

Nizamani, I.A., Talpur, M.A., Khuhro, R.D., Nizamani, S.M., 2002. Relative resistance of cotton cultivars to sucking complex. Pakistan Journal of Applied Sciences 2, 686-689.

Sharaf, N., 1986. Chemical control of Bemisia tabaci. Agriculture, Ecosystems \& Environment 17, 111127.

Solangi, B.K., Lohar, M.K., 2007. Effect of some insecticides on the population of insect pests and predators on okra. Asian Journal of Plant Sciences 6, 920-926.

Zhang, L., Greenberg, S.M., Zhang, Y., Liu, T.X., 2011. Effectiveness of thiamethoxam and imidacloprid seed treatments against Bemisia tabaci (Hemiptera: Aleyrodidae) on cotton. Pest Management Science 67, 226-232. 